\title{
Influence of E-commerce Development on international trade Development in Present Era
}

\author{
Fang Wang \\ Guangdong College of Foreign Language and Arts, Guangzhou Guangdong, 510000, China
}

Keywords: E-Commerce, International trade, Development, Influence

\begin{abstract}
The application of e-commerce in international trade brings large changes in international trade. Under e-commerce environment, international trade is developing to informatization direction. So, international trade and e-commerce have close relevance. E-commerce generates certain influence on the development of international trade. The emergence of e-commerce promotes continuous expansion of the scope of international trade subjects and plays a significant role in driving national economic growth. International trade development presents a good situation. However, e-commerce restricts international trade development to some degree. In particular, the loss of taxes generates good influence on international trade. Thus, this paper analyzes the influence of e-commerce on international trade development in present era and proposes main measures to promote international trade so as to facilitate global economic development.
\end{abstract}

\section{Introduction}

In present era, e-commerce which is commercial transaction activity carried out by computer technology and network technology is becomes social mainstream. Under the background of trade globalization, low cost and high efficiency of e-commerce contribute to international trade development to some degree. As information technology keeps improving, the activity efficiency under systematic network platform and e-commerce improves. Under e-commerce background, the distance between transaction parties becomes close. Thus, target groups increase to some degree. E-commerce becomes the main transaction mode of international trade. To promote international trade development, it is required to give full play to the advantage of e-commerce and improve economic growth speed.

\section{Connotation of e-commerce}

E-commerce means under internet environment, the buyer and the seller can trade via Internet browser, or consumers purchase online and merchants achieve online transaction and e-payment. E-commerce appeared in 1990s. The concept of e-commerce was proposed by IBM Corporation. Later, UN and national governments have different understandings of e-commerce. In a broad sense, e-commerce implements various activities with the help of electronic technology. Both selling and procurement plan are conducted by e-commerce. Meanwhile, international trade not just increases business opportunities, but also reduces the cost through the application of e-commerce.

Usually, e-commerce has the following features: firstly, high execution efficiency. E-commerce mainly adopts electrommunication means. Under the conditions of mathematicization and electronization, the links of information transmission are fewer, and the efficiency is high. In particular, the application of block-switch technology can greatly improve information transmission rate of e-commerce activities and reduce cost. Secondly, networked and convenient delivery. With e-commerce development, the buyer and the seller can achieve settlement via Internet and complete trade with the help of e-payment, e-bank and other financial means. Thirdly, openness and globalization. With global development of economy and trade, more opportunities are brought for enterprises. In economy and trade development process, e-commerce offers more channels for development of trade activities because of its openness and globalization features. 


\section{Influence of e-commerce development on international trade}

\section{E-commerce influences international trade operation mode}

The emergence of e-commerce alters international trade operation mode. As an emerging trade mode, e-commerce to some extent promotes favorable development of international trade. Under traditional international trade mode, distribution, agency and consignment businesses are restricted by the intermediate link. However, e-commerce development brings large changes in international trade mode. Under electronic data interchange, goods, information and capital can flow at a high speed with the help of internet to make sure international trade becomes more direct. Hence, e-commerce development generates corresponding influence on international trade operation mode. At the same time, e-commerce is based on network information. With the application of e-commerce information internet in international trade, relevant personnel can know information in time and then make decisions. Hence, e-commerce development promotes transformation of international trade operation mode to some degree.

\section{E-commerce influences international trade transaction means}

In international trade development process, traditional transaction tools include phone, fax and letters etc. Since the appearance of e-commerce, international trade transaction cost and expense drop sharply under the function of network sale and electronic document electronization. Transaction tool electronization greatly facilitates good development of international trade. At the same time, international trade payment method also achieves electronization. Buyers can pay via alipay and e-bank. Such payment method has high efficiency, reforms traditional method ad alters the defects of low payment efficiency. Besides, goods payment mode is electronized. The development of e-commerce makes international trade payment based on e-comemrce form. Under the function of professional third-party logistics, payment security is higher, and the efficiency is also higher, which greatly facilitates fast payment of service trade. Therefore, e-commerce development generates certain influence on the emergence of international trade.

\section{E-commerce influences logistics cost of international trade}

E-commerce development directly influences logistics cost of international trade. E-commerce promotes achievements of zero stock and makes sure enterprises sell via international internet. Third-party professional logistics companies implement good distribution. Thus, to some degree, trade enterprises make the best of e-commerce to greatly reduce the quantity of goods in stock (even no stock), finally make sure trade enterprises reach zero stock and achieve the objective of saving logistics cost. In addition, in traditional background, usually trade enterprises transport goods by international trade agency and then complete trade through "ship chartering and space booking" . But such mode has high cost, complex formalities and poor security. However, with rapid development of e-commerce, third-party logistics becomes more professional, and product transportation convenience is brought. Meanwhile, transportation cost is greatly cut down. To some extent, the emergence of e-commerce greatly drives favorable development of international trade. Online trade and payment can be conducted in international trade development process, without the need of setting up warehousing facilities.

\section{Problems of China's international trade in international trade}

\section{Legal problem}

Although e-commerce development plays a role in international trade development, many problems exist. In e-commerce background, legal problem is one of major problems in international trade. In virtual network environment, it is hard to effectively verify data authenticity. Thus, the difficulty in verifying data increases. In the development process, international trade fully applies e-commerce. To reduce risks, electronic billing must be mastered in time so as to make sure international trade activity can achieve good effects. However, in e-commerce environment, how to adopt and apply electronic billing evidence is a main problem in international trade law and regulation construction. At present, certification and signature of various countries fail to form uniform standard. Even if there is Electronic Signature System, the provisions of various countries 
have a large gap. Moreover, laws and taxation are not uniform. In particular, international trade taxation in e-commerce background has disputes, and there is no uniform definition about service trade taxation and goods trade taxation. Thus, e-commerce imposes adverse effects on international trade development ${ }^{[1]}$.

\section{Security problem}

Although e-commerce facilitates international trade development, it also results in security problem in e-commerce background. Under virtual network environment, e-commerce gives rise to many potential security hazards in international trade. For internet fraud, fraudulent behavior may easily occur under network trade when both parties sign the contract. Since e-commerce serves as the platform, the goods are displayed to consumers in the form of pictures. However, the pictures have a large gap with actual goods. Besides, after-sale service cannot be guaranteed. Network hackers viciously modify business time and address. When consumers trade online, e-payment mode may easily suffer attack of virus, which will result in fund security problem. Further, security risk exists in international trade transaction. Moreover, management risk is also one of the risks. Under e-commerce background, international trade is characterized by trans-region and trans-nation. However, each country has management right problem and even tax transfer and repeated taxation phenomena exist. All these increase management difficulty. When consumers trade online, e-payment mode may easily suffer attack of virus, which will result in fund security problem.

\section{Infrastructure construction problem}

International trade development is supported by e-commerce and must be based on sound infrastructure construction. But in current stage, a large gap still exists between China and America in terns of e-commerce infrastructure construction and technology. America has established high-velocity electronic communication network which is composed of communications satellite and seabed light ${ }^{[2]}$. Nevertheless, insufficient fund input exists in China' s e-commerce infrastructure construction process. Numerous problems exist in e-commerce infrastructure construction link. Although Tianjin, Shanghai and other large cities pay much attention to e-commerce infrastructure construction and have formed certain scale in electric energy popularization and optical cable laying, most remote areas fail to establish branches, and e-commerce information construction remains improving, thus adverse to favorable development of international trade.

\section{Effective measures to facilitate international trade development through e-commerce}

\section{To energetically train e-commerce talents}

At present, e-commerce drives good development of international trade in international trade development process and e-commerce background. To make sure e-commerce exerts its huge function, the state needs to train e-commerce talents and create favorable conditions for international trade development ${ }^{[3]}$. During energetically training e-commerce talents, colleges should give play to their functions, regard e-commerce talent training as the main objective of education, enhance e-commerce subject construction force, reform educational system, train interdisciplinary talents and finally facilitate international trade development.

\section{To strengthen e-commerce infrastructure construction}

In order to promote favorable development of international trade by e-commerce, international trade development can get rid of network infrastructure restriction and make enterprises achieve sustainable development through enhancing e-commerce infrastructure construction ${ }^{[4]}$. Currently, China is still faced with technology, fund and other problems in e-commerce development process.

"Information immiserization" is ma major factor restricting e-commerce information infrastructure construction. Therefore, as e-commerce develops rapidly, it is required to enhance attention to e-commerce infrastructure construction in order to promote international trade development. Firstly, increase investment. To improve e-commerce infrastructure construction and facilitate high-speed development of international trade, fund investment must be increased, and e-commerce network infrastructure construction should be perfected so as to improve internal structure of e-commerce network. Secondly, rationally apply e-commerce network resource. During 
enhancing e-commerce infrastructure construction, e-commerce network resource must be fully utilized, and the limit of traditional industry management system must be broken so that e-commerce infrastructure construction can drive international trade development. Thirdly, set up a distribution center. In e-commerce environment, a distribution center which integrates logistics, business flow and information flow must be set up in order to facilitate favorable and fast development of international trade. In one word, during e-commerce development, e-commerce infrastructure construction must be enhanced in order to accelerate international trade development. Then, e-commerce can give play to its huge role and create conditions for international trade development through perfecting the infrastructure.

To establish sound e-commerce trade market system

In a bid to effectively standardize international trade behavior and avoid fake and shoddy goods, sound e-commerce trade market system should be established under e-commerce development background. International trade e-commerce activity is based on network, so it is required to standardize nonstandard market behavior through creating secure and mature market and establishing sound e-commerce transaction market system $^{[5]}$. As well, product quality standard system and e-commerce market system should be established and executed in strict accordance with the system so as to ensure sustainable development of e-commerce and finally facilitate international trade development.

\section{Conclusion}

The emergence of e-commerce plays a significant role for international trade development. Some trade enterprises also realize the importance of e-commerce, and e-commerce development generates great influence on international trade. Meanwhile, the superiority of e-commerce is highlighted. Enterprises adjust operation and development mode according to features of commercial activities under e-commerce environment. However, e-commerce development also exerts some influence on e-commerce and even has some problems. Thus, in order to promote rapid development of international trade, it is required to continuously improve e-commerce development mode, apply e-commerce effectively in international trade and adopt effective measures to facilitate rapid development of international trade under e-commerce environment.

\section{References}

[1] Meng Xianjun, Liu Ying, On Influence of E-commerce on International Trade Development. Heilongjiang Science and Technology Information, 2013(6):113.

[2] Huang Qian, Study on Influence of E-commerce on International Trade and Corresponding Countermeasures. Times Finance (II), 2014(10):207,219.

[3] Ma Chen, Combination and Development of International Trade and E-commerce Platform. Business Horizon, 2014(4):475-476.

[4] Qiao Yang, Shen Meng, Liu Jie et al. Influence of E-commerce on International Trade and Application Status. Foreign Trade, 2012(3):39-41.

[5] Song Tian, Study on Influence of E-commerce on International Trade and Development Strategy. China Business \& Trade, 2013(30):49-49,100. 